\title{
Distribution and Morphology of Ghrelin-Immunopositive Cells in the Thymus of the African Ostrich
}

\author{
Distribución y Morfología de Células Inmunopositivas de la \\ Ghrelina en el Timo de la Avestruz Africana
}

Jia-xiang Wang; Peng Li; Xiao-ting Zhang \& Li-xun Ye

WANG, J. X.; LI, P.; ZHANG, X. T. \& YE, L. X. Distribution and morphology of ghrelin-Immunopositive cells in the thymus of the African ostrich. Int. J. Morphol., 35(2):541-546, 2017.

SUMMARY: Ghrelin, an endogenous ligand for the growth hormone secretagogue receptor, has been detected in the thymus of multiple vertebrates. However, little is known about its distribution in the thymus of the African ostrich. In this study, we evaluated the distribution and morphological characteristics of ghrelin-producing cells in the thymus of the African ostrich. Our results revealed that the thymus consists of a capsule and a parenchyma, which comprises the cortex and medulla. Compared to the cortex, the medulla had a fewer number of thymocytes and a greater number of epithelial cells. Additionally, three thymic corpuscles were identified. Ghrelinimmunopositive (ghrelin-ip) cells were detected both in the cortex and medulla of the African ostrich thymus, specifically within epithelial cells and thymic corpuscles. On the other hand, no ghrelin-ip cells were detected within thymocytes. These results clearly demonstrate the presence of ghrelin-ip cells in the thymus of the African ostrich.

KEY WORDS: African ostrich; Ghrelin; Thymus; Immunohistochemistry.

\section{INTRODUCTION}

Ghrelin is a brain-gut peptide that was isolated as an endogenous ligand for the growth hormone secretagogue receptor in the rat stomach (Kojima et al., 1999). The peptide contains 28 amino acids and has an n-octanoylated residue (serine-3) (Kojima et al., 1999). Ghrelin has several functions; specifically, the peptide stimulates the release of growth hormone from the pituitary gland, increases food intake, mediates energy homeostasis, enhances gastrointestinal motility, and regulates insulin levels and glycaemia (Kojima et al., 1999; Kirchner et al., 2012; Perello \& Dickson, 2015; Alamri et al., 2016). Additionally, ghrelin serves as a potent anti-inflammatory mediator that has broad application potential in the treatment of inflammatory diseases and injuries (Azizzadeh et al., 2016; Stasi \& Milani, 2016). Furthermore, the peptide promotes thymopoiesis by increasing lymphoid progenitors (Dixit et al., 2007).

Studies have shown that ghrelin is widely conserved in both mammals and non-mammals (Kojima et al., 2008). In non-mammalian vertebrates, ghrelin has been purified from gastric extracts. Kaiya et al. (2002) observed that ghrelin immunoreactivity and mRNA expression were primarily detected in the stomach and intestines. Subsequently, ghrelin immunoreactivity and mRNA expression were detected in several other organs of nonmammalian vertebrates. Additionally, there appears to be species-specific differences in ghrelin distribution and expression (Kaiya et al., 2008). In the thymus, ghrelinimmunopositive (ghrelin-ip) cells have been found in broiler chickens, ducks, and white leghorns (Wei et al., 2010; Yu et al., 2012; Yuan et al., 2014).

In the African ostrich, ghrelin has been detected in the stomach, intestines, and cerebellum (Wang et al., 2009; Wang et al., 2012). However, no studies have evaluated the distribution of ghrelin in the thymus of the African ostrich. To understand the physiological role of newly identified peptides, it is important to know the morphological characteristics of the synthesizing cells and their distribution. Therefore, in this study, we evaluated the distribution and morphological characteristics of ghrelin-ip cells in the thymus of the African ostrich. 


\section{MATERIAL AND METHOD}

Animals. African ostriches (age, 8 months; weight, $70.68 \pm 2.25$ $\mathrm{kg}$ ) were used in this study. African ostrich $(2$ females and 2 males) were obtained from the Ostrich Research Institute of Yangtze University in Hubei Province, China, where feed and water were made available ad libitum. All of the birds were maintained in a heated room with slatted plastic floor and were fed a starter diet for postnatal days 7 , which was formulated according to the specifications of the Elsenburg Ostrich Feed Database (Brand, 2010). All procedures were approved by the Animal Care and Welfare Committee of our Institute.

Tissue preparation. The ostriches were deeply anesthetized with $10 \%$ urethane (Caoyang Secondary Chemical Plant, Shanghai, China) at a dose of $1 \mathrm{~g} / \mathrm{kg} \mathrm{BW}$, and perfused initially with $1000 \mathrm{~mL}$ of $0.85 \%$ normal saline (containing $0.075 \%$ sodium citrate) and thereafter with $1500 \mathrm{~mL}$ of $4 \%$ paraformaldehyde phosphate-buffered solution $(0.1 \mathrm{~mol} / \mathrm{L}, \mathrm{pH}$ 7.4) at $4{ }^{\circ} \mathrm{C}$. The Chest and neck was cut open, and the all thymus were quickly removed, and gently flushed with 0.85 $\%$ normal saline to remove the content, then be postfixed for more than $24 \mathrm{~h}$ with $4 \%$ paraformaldehyde. After immersion, the tissues were embedded in paraffin. Serial sections $(5 \mu \mathrm{m})$ were cut on a Leica microtome (Nussloch Gmbh, Germany), 2 suit sections were prepared; one suit was stained by haematoxylin and eosin (H\&E) to observe the cytoarchitecture of thymus; the other was stained by immunohistochemistry (SABC) to observe the distribution, morphological characteristics of ghrelin-producing cells in the thymus of the African ostrich.

Immunohistochemistry. Immunohistochemical detection of ghrelin cells using rabbit anti-ghrelin was carried out by the streptavidin-biotin-peroxidase complex (SABC) method. The production and specificity of the anti-human ghrelin serum used in this study were previously reported (Wang et al. 2009); it is established that this antiserum recognizes both $\mathrm{N}$ - and Cterminial of human ghrelin. Immunohistochemical staining was performed according to the following procedure. The sections were deparaffinized with xylene and rehydrated with decreasing concentrations of ethanol, then treated with $3 \%$ hydrogen peroxide $\left(\mathrm{H}_{2} \mathrm{O}_{2}\right)$ to block endogenous peroxidase for $10 \mathrm{~min}$ at room temperature. After rinsing with distilled water, the sections were incubated with a citrate buffer $(\mathrm{pH}$ 6.0) and placed in a microwave oven until the water boiled to fully expose the antigen. After rinsing with phosphate-buffered saline (PBS), the sections were incubated with $5 \%$ normal goat serum for $20 \mathrm{~min}$. After removing superfluous liquid, the sections were incubated with rabbit anti-ghrelin serum
(BA1619; Boster Corporation) diluted 1:100 in PBS for $12 \mathrm{~h}$ in a humid chamber at $4{ }^{\circ} \mathrm{C}$. After washing with PBS for 6 min, a second incubation with biotin-conjugated anti-rabbit IgG serum (SA1022; Boster) was carried out for $20 \mathrm{~min}$, and this was followed by further washing with PBS. Finally, the sections were incubated for $20 \mathrm{~min}$ with an SABC solution prepared according to the manufacturer's instructions. After washing with PBS for $20 \mathrm{~min}$, the sections were reacted in a diaminobenzidine-tetrachloride kit (DAB kit, AR1022, Boster Corp) for $30 \mathrm{~min}$ to detect immunostaining. After washing with distilled water, the sections were dehydrated with a graded ethanol series, cleared in xylene, mounted with a coverslip, and viewed under a light microscope (BH-2; Olympus, Japan). All of the incubations were carried out in a humid chamber at room temperature. Control sections were prepared using the same method, omitting the primary antibody. To examine the specificity of rabbit anti-human ghrelin antiserum, the diluted antiserum (1:100) was incubated with human ghrelin (5 mg/ $\mathrm{ml}$ ) at room temperature for $10 \mathrm{~h}$, and mixtures were centrifuged at $12000 \mathrm{rpm}$ for $25 \mathrm{~min}$ at $4{ }^{\circ} \mathrm{C}$. The supernatant was used as the primary antiserum for absorption tests.

Morphometric analysis. For each thymus tissue sample, 3 cross-sections were prepared after the samples had been stained with hematoxylin and eosin and SABC stain. Further, for each thymus cross-section, 10 intact, well-oriented units were selected for experiments conducted in triplicate $(30$ measurements for each sample). After taking digital photographs under a light microscope with a digital camera (COOLPIX 4500; Nikon, Japan).

\section{RESULTS}

The results presented are those obtained from both female and male chicks; no gender-specific effects were observed.

Cytoarchitecture of the thymus in the African ostrich. The thymus of the ostrich was divided into two sections, (1) an outer membrane and (2) an inner parenchyma (Fig. 1A). The membrane stretched into the thymic parenchyma and formed septa interlobulare, and the thymic parenchyma was divided into a number of lobules (Fig. 1A). Each lobule included the cortex and the medulla (Fig. 1A). The cortex was located on the surface and contained a large number of thymocytes, resulting in a deep color (Fig. 1B). The medulla was located in the core. The septa interlobulare was not completely separated, the adjacent lobular medullae were interconnected, and there were more vessels in the medulla than in the cortex. Compared to the cortex, the medulla had a fewer number of thymocytes and a greater number of epithelial cells (Fig. 1C); 
therefore, the color was less intense. Thymic corpuscles could be observed in the medulla. Three types of thymic corpuscles were identified, one that was homogeneously red-stained with single-cell structure (Fig. 1C), one with a typical concentric arrangement (Fig. 1D), and one that was formed by an irregular arrangement of cells (Fig. 1D).

Distribution of ghrelin-immunopositive cells in the thymus. Ghrelin-ip cells were detected in the cortex and
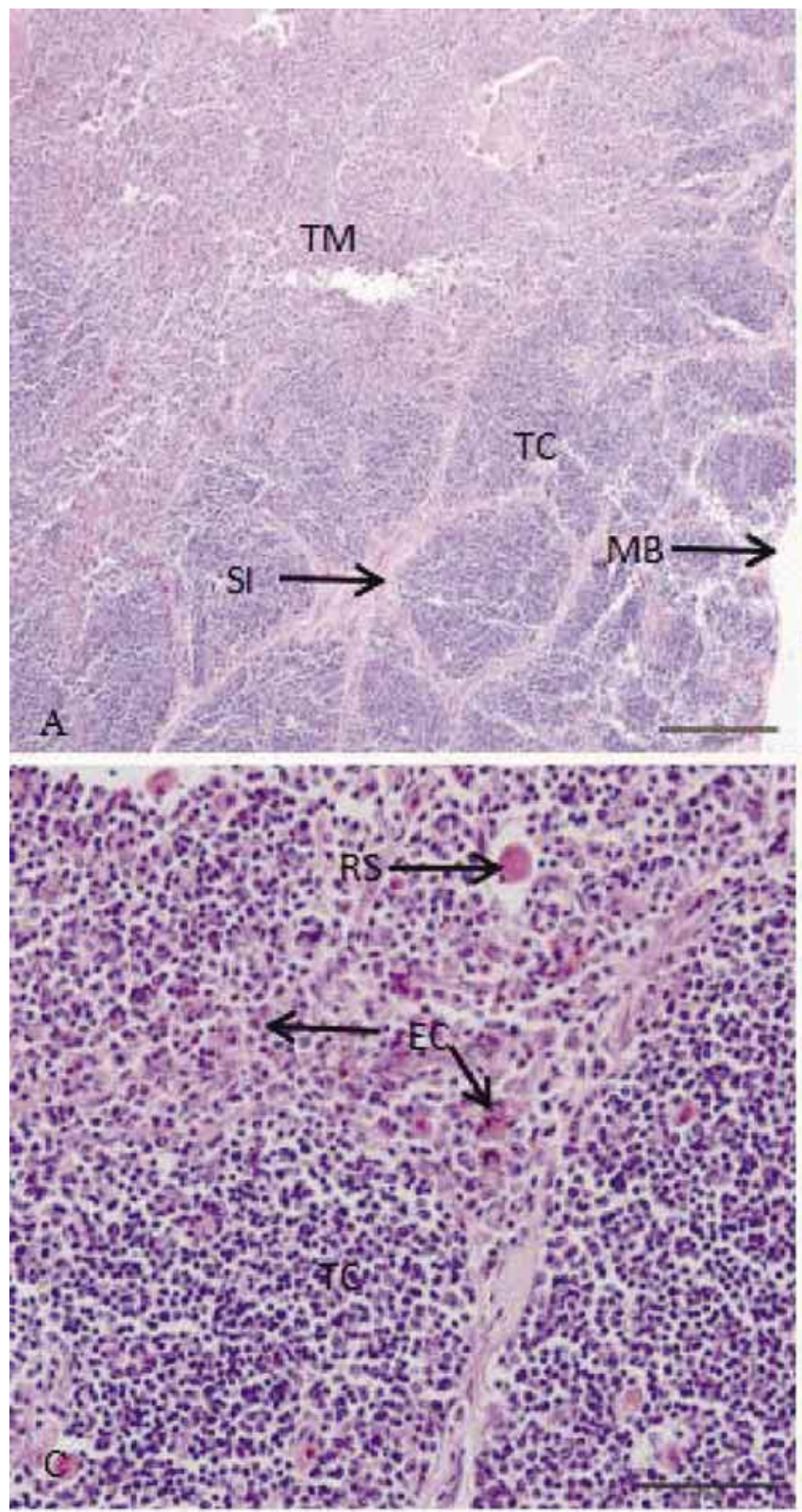

medulla of the thymus. The greatest number of ghrelin-ip cells was found in the medulla (Fig. 2A). In the cortex, ghrelin-ip cells were located within epithelial cells. The cytoplasm of ghrelin-ip cells was stained, and the cells were round or oval in shape (Fig. 2B). Similarly, ghrelin-ip cells in the medulla were located within epithelial cells and thymic corpuscle. The cells exhibited a stained cytoplasm and were round or oval in shape (Fig. 2C). The absorption test results using antiserum revealed the complete disappearance of immunoreactivity in the thymus (Fig. 2D).
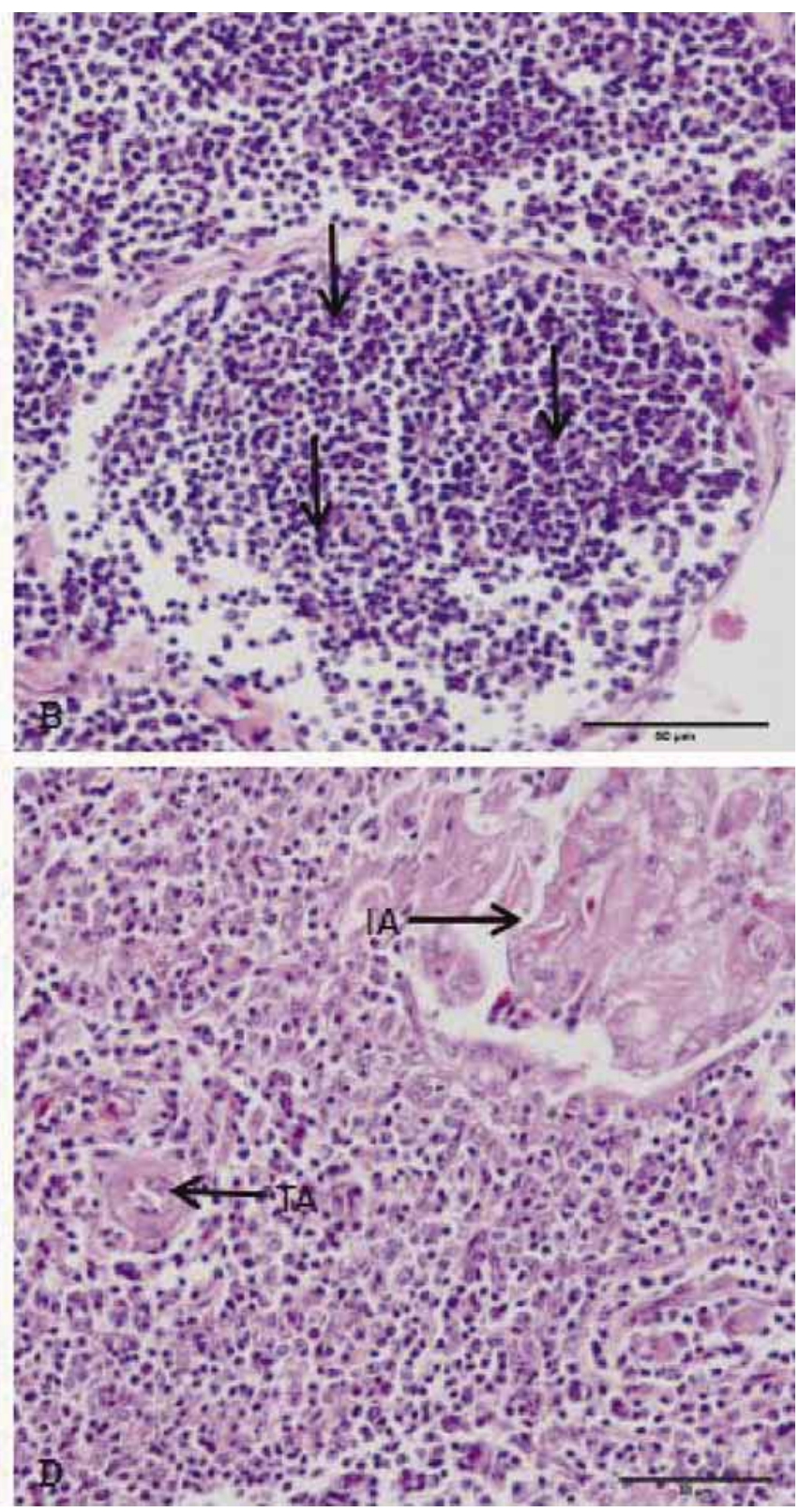

Fig. 1. Photomicrographs of the thymus of the African ostrich (HE staining). (A) Thymus. (B) Thymocytes (arrows) were detected in the cortex. (C) Thymus. (D) Medulla. (MB, membrane; TC, cortex; TM, medulla; SI, septa interlobular; EC, epithelial cell; RS, thymic corpuscle; red-stained with single-cell structure); TA, thymic corpuscle (typical concentric arrangement); IA, thymic corpuscle (irregular arrangement). Scale bar: A, $200 \mu \mathrm{m}$; B-D, $50 \mu \mathrm{m}$. 

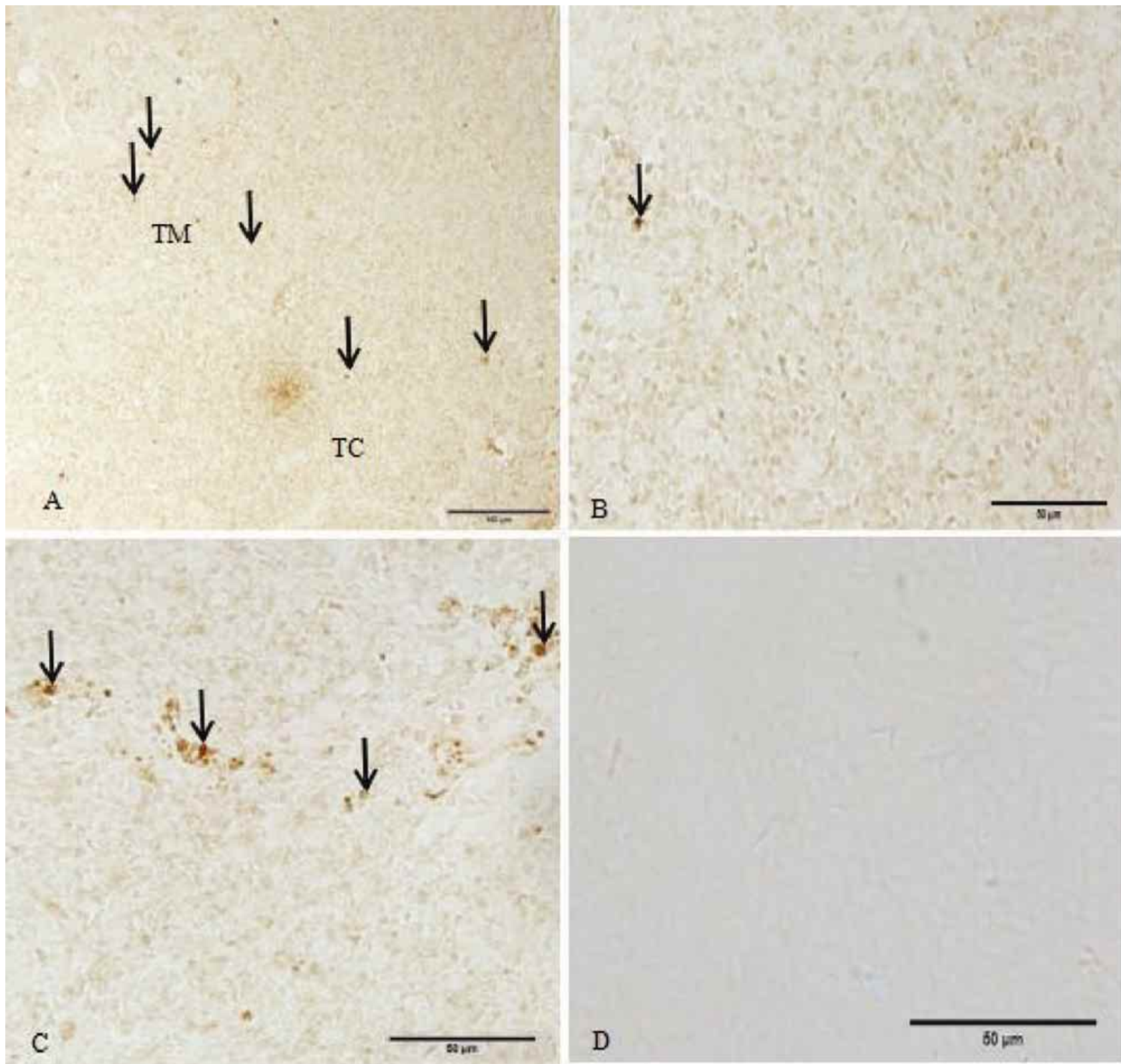

Fig. 2. Photomicrographs of ghrelin-immunopositive (ghrelin-ip) cells in the thymus of the African ostrich (SABC staining). (A) Ghrelinip cells (arrows) were detected in the thymus. (B) Ghrelin-ip cells (arrows) surrounding the epithelial cells of the cortex. (C) Ghrelin-ip cells (arrows) within the epithelial cells of the medulla. (D) Photomicrograph of absorption tests in the thymus. TC, cortex; TM, medulla. (A) Scale bar: $200 \mathrm{~mm}$; (B-D) Scale bar: $50 \mathrm{~mm}$.

\section{DISCUSSION}

The thymus is critical in the development, selection, and maintenance of the peripheral $\mathrm{T}$ cell pool. The mammalian thymus is capable of generating $\mathrm{T}$ cells throughout its life span (Dixit et al.). However, after puberty and with advanced age, the thymic space becomes progressively filled with adipocytes and there is a dramatic loss of thymocytes in the cortical and medullary areas, leading to a reduction in the synthesis of $\mathrm{T}$ cells. This process is referred to as thymic involution (Taub \& Longo, 2005). In the present study, we observed that the thymus of the African ostrich was divided into two parts, 1) a capsule and 2) a parenchyma, which comprises the cortex and medulla. 
The cortex had a large number of thymocytes. The medulla was located in the core of the thymus. Compared to the cortex, the medulla had fewer thymocytes and more epithelial cells. There were three types of thymic corpuscles in the ostrich thymus, which were similar in structure to those observed in broiler chickens, ducks, and white leghorns (Wei et al.; Yu et al.; Yuan et al.). However, Yuan et al. reported that thymic involution occurred at 20-32 weeks of age in ducks and 35-120 days of age in chickens. Our study findings revealed that thymus involution does not occur within the first eight months of life of the African ostrich. Therefore, thymic involution occurs at a later stage in the African ostrich.

Ghrelin-ip cells have been detected in broiler chickens, ducks, and white leghorns (Wei et al.; Yu et al.; Yuan et al.); however, there appears to be species-specific differences. In broiler chickens, ghrelin-ip cells have been identified in thymic epithelial cells, thymic corpuscles, and macrophages (Wei et al.). In the duck thymus, ghrelin-ip cells were found mainly in thymic epitheilial cells and macrophages, but not in thymic corpuscles (Yuan et al.). In white leghorns, ghrelin-ip cells were detected mainly in thymic epitheilial cells and macrophages in the medulla (Yu et al.). In this study, ghrelin-ip cells were detected in both the cortex and medulla of ostrich thymus. Specifically, ghrelin-ip cells were located within epithelial cells and thymic corpuscles, in accordance with the findings reported in broiler chickens, ducks, and white leghorns (Wei et al.; Yu et al.; Yuan et al.) However, Xu et al. (2010) reported no ghrelin mRNA expression in the thymus of the giant panda, thereby confirming that the distribution and expression of ghrelin in the thymus is species-specific.

Recently, Dixit et al. observed that ghrelin promotes thymopoiesis by increasing lymphoid progenitors. Moreover, Taub et al. (2010) demonstrated that ghrelin significantly improved the thymic architecture by contributing to defined cortical and medullary regions, increasing thymocyte number, and thymus weight. Interestingly, ghrelin increased the numbers of cortical and medullary epithelial cells, possibly playing a role in the restructuring of aged thymi (Taub et al.). We detected ghrelin-ip cells within epithelial cells of the cortex and medulla of the African ostrich thymus. Therefore, ghrelin may play a role in the regulation of thymopoiesis and in the development of the thymus. However, the specific relationship between the distribution and function of ghrelin-ip cells in the thymus of the African ostrich requires further research.

\section{CONCLUSION}

The thymus of the African ostrich has its own unique characteristics. Specifically, the thymus of the African ostrich is divided into two parts, a capsule and a parenchyma, which comprises the cortex and medulla. Compared to the cortex, the medulla had fewer number of thymocytes but a greater number of epithelial cells. Additionally, three types of thymic corpuscles were detected. Ghrelin-ip cells were present within the epithelial cells and thymic corpuscles of the cortex and medulla. Ghrelin promotes thymopoiesis by increasing the lymphoid progenitors. Thymic involution in the ostrich occurs at a later stage than in chickens or ducks. Therefore, our study findings suggest that ghrelin may play a role in the regulation of thymopoiesis and in the development of the thymus. However, the specific relationship between the distribution and function of ghrelin-ip cells in the thymus of the African ostrich requires further research.

\section{ACKNOWLEDGEMENTS}

We would like to thank the National Natural Science Foundation Project of China. This work was supported by the National Natural Science Foundation Project of China, No.31402152.

WANG, J. X.; LI, P.; ZHANG, X. T. \& YE, L. X. Distribución y morfología de células inmunopositivas de la ghrelina en el timo de la avestruz Africana. Int. J. Morphol., 35(2):541-546, 2017.

RESUMEN: La ghrelina, un ligando endógeno para el receptor secretor de la hormona del crecimiento, se ha detectado en el timo de múltiples vertebrados. Sin embargo, poco se sabe sobre su distribución en el timo de la avestruz africana. En este estudio se evaluó la distribución y características morfológicas de las células productoras de ghrelina en el timo de la avestruz africana. Nuestros resultados revelaron que el timo consiste en una cápsula y un parénquima, que comprende la corteza y la médula. En comparación con la corteza, se observó un número menor de timocitos en la médula y un mayor número de células epiteliales. Además, se identificaron tres corpúsculos tímicos. Se detectaron células inmunopositivas a la ghrelina (ghrelin-ip) tanto en la corteza como en la médula del timo de la avestruz africana, específicamente dentro de células epiteliales y corpúsculos tímicos. Por otra parte, no se detectaron células ghrelinip dentro de los timocitos. Estos resultados demuestran claramente la presencia de células ghrelin-ip en el timo de la avestruz africana.

PALABRAS CLAVE: Avestruz africana; Ghrelina; Timo; Inmunohistoquímica. 


\section{REFERENCES}

Alamri, B. N.; Shin, K.; Chappe, V. \& Anini, Y. The role of ghrelin in the regulation of glucose homeostasis. Horm. Mol. Biol. Clin. Invest., 26(1):3-11, 2016.

Azizzadeh, F.; Mahmoodi, J.; Sadigh-Eteghad, S.; Farajdokht, F. \& Mohaddes, G. Ghrelin exerts analgesic effects through modulation of IL-10 and TGF-b levels in a rat model of inflammatory pain. Iran. Biomed. J., 21(2):114-9, 2016.

Brand, T. S. Elsenburg Ostrich Feed Databases. Elsenburg, Elsenburg Agricultural Research Centre, 2010.

Dixit, V. D.; Yang, H.; Sun, Y.; Weeraratna, A. T.; Youm, Y. H.; Smith, R. G. \& Taub, D. D. Ghrelin promotes thymopoiesis during aging. J. Clin. Invest., 117(10):2778-90, 2007.

Kaiya, H.; Van der Geyten, S.; Kojima, M.; Hosoda, H.; Kitajima, Y.; Matsumoto, M.; Geelissen, S.; Darras, V. M. \& Kangawa, K. Chicken ghrelin: purification, cDNA cloning, and biological activity. Endocrinology, 143(9):3454-63, 2002.

Kaiya, H.; Miyazato, M.; Kangawa, K.; Peter, R. E. \& Unniappan, S. Ghrelin: a multifunctional hormone in non-mammalian vertebrates. Comp. Biochem. Physiol. Part A Mol. Integr. Physiol., 149(2):109-28, 2008.

Kojima, M.; Hosoda, H.; Date, Y.; Nakazato, M.; Matsuo, H. \& Kangawa, $\mathrm{K}$. Ghrelin is a growth-hormone-releasing acylated peptide from stomach. Nature, 402(6762):656-60, 1999.

Kojima, M.; Ida, T. \& Sato, T. Structure of mammalian and nonmammalian ghrelins. Vitam. Horm., 77:31-46, 2008.

Kirchner, H.; Heppner, K. M. \& Tschöp, M. H. The role of ghrelin in the control of energy balance. Handb. Exp. Pharmacol., (209): 161-84, 2012.

Perello, M. \& Dickson, S. L. Ghrelin signalling on food reward: a salient link between the gut and the mesolimbic system. J. Neuroendocrinol., 27(6):424-34, 2015.

Stasi, C. \& Milani, S. Functions of ghrelin in brain, gut and liver. C. N. S. Neurol. Disord. Drug Targets, 15(8):956-63, 2016.

Taub, D. D. \& Longo, D. L. Insights into thymic aging and regeneration. Immunol. Rev., 205:72-93, 2005.

Taub, D. D.; Murphy, W. J. \& Longo, D. L. Rejuvenation of the aging thymus: growth hormone-mediated and ghrelin-mediated signaling pathways. Curr. Opin. Pharmacol., 10(4):408-24, 2010.

Wang, J. X.; Peng, K. M.; Liu, H. Z.; Song, H.; Chen, X. \& Liu, M. Distribution and developmental changes in ghrelin-immunopositive cells in the gastrointestinal tract of African ostrich chicks. Regul. Pept., 154(13):97-101, 2009.

Wang, J. X.; Li, P. \& Zhou, Y. Distribution and morphology of ghrelinimmunopositive cells in the cerebellum of the African ostrich. Tissue Cell, 44(6):373-7, 2012.

Wei, F.; Li, Y.; Ye, Y.; Zhang, Z.; Ma, Y. \& Jiang, Q. Localization and development of ghrelin-immunopositive cells in periphery organs of broiler chickens. Acta Vet. Zootech. Sin., (3):341-6, 2010.

Xu, Q.; Bian, H.; Han, N.; Hou, R.; Zhang, Z. \& Zhu, M. cDNA cloning and expression of ghrelin in giant panda (Ailuropoda melanoleuca). Mol. Biol. Rep., 37(6):2903-7, 2010.

Yuan, Y.; Fang, J.; Liao, T. B.; Cui, X. \& Chen, Y. Immunohistochemical localization and developmental changes of ghrelin in the duck thymus. J. South China Agric. Univ., 35(6):19-23, 2014.

Yu, Y.; Ma, J. Y. \& Xu, Z. Y. Distribution and location of immunopositive cells in the thymus of White Leghorns. China Poult., 34(3):62-3, 2012.

\author{
Corresponding author: \\ Jia-xiang Wang \\ Department of Anatomy \\ Histology and Embryology \\ College of Animal Science \\ Yangtze University \\ 1 Nanhuan Road \\ Jingzhou, Hubei \\ P. R. CHINA
}

E-mail: Wangjiaxiang1109@163.com.

Received: 04-01-2017

Accepted: 21-03-2017 